\title{
Nakedness and Movement Culture
}

\author{
Ivo Jirásek
}

Palacký University in Olomouc, Czech Republic

\begin{tabular}{l|l}
\hline & ABSTRACT \\
\hline kinanthropology; it concerns the phenomenon of the naked body in the \\
environment of movement culture. Within the individual aspects of this \\
cultural subsystem (sport, movement education, movement recreation, \\
movement therapy, and movement art), it points out a variety of meanings \\
and contexts adding sense to nudity on a continuum ranging from \\
naturalness and functionality through erotization and sexualization to \\
pornoization of particularly sport environment. The author prefers a \\
functional naturalness of nudity and rejects the instrumentalization and \\
changing human body into a thing and, thus, exceeding the characteristics \\
of the sphere of movement culture. \\
nudity, movement culture, sexualization of sport, pornoization of sport, \\
naturalness
\end{tabular}

\section{Cultural dimension of nudity}

An undressed human body is given by nature (humans are born naked), however, it is evident that the meaning and purpose of nudity is determined exclusively by the cultural and social environment (shame is realized along with the process of socialization and education of an individual), by a set of values ascribed to nudity in a given cultural background.

In this sense, the body without any clothing can be a sign of religiosity and spirituality. The Marshall in Mesopotamia, for example, had to be physically flawless when he performed religious rituals and contacted God naked (Heller 1988). Within Christianity, we can observe both a certain distance from physical nudity and its emphasis, as in the sect of the Adamites, in reports related to the phenomenon of witchcraft and inquisition, but also in the interconnection of mythical and erotic images (the issue of the relationship of religious imagination regarding nudity and sexuality in Colonial Mexico in the $17^{\text {th }}$ century is deeply explored by Tortorici, 2007). And eastern spirituality, as for example in Hinduism or rituals of Tantra, is inconceivable without naked human bodies, as can be seen not only in the decoration of temples depicting copulating couples that represent a connection of cosmic energies.

The undressed body can also be a sign of protest and political struggle, be it for the rights of minorities (notably communities with a different sexual orientation), for animal rights and especially anti-war demonstrations. Diversified forms of protest ranging from groups of naked cyclists through inscriptions painted on naked bodies to individual letters on each body creating a "no war" sign on a line of naked people has a common denominator: the naked body is perceived as something unnatural, something whose purpose is to attract the attention of society. Also political aspects of colonialism and 
racism can be analyzed from a certain point of view dealing with nudity (Krüger 1991, Levine 2008, Payne 2000/2001). What also belongs to the same group emphasizing nudity as a tool for gaining attention are commercials using nudity with a growing intensity of sexuality, or "naked news", where it is very difficult to find a connection between stripping announcers and their simultaneous reporting on social events.

Different meaning is ascribed to nudity in the field of art: if we removed all artefacts displaying the naked human body from the history of art, we would lose a significant part of human self-reflection. Paintings, statues, photos but also films and happenings displaying or using naked human bodies have one thing in common, namely an idea of searching for beauty, even though it may be visualized by opposite techniques implementing entirely different criteria. Penetrating art and other meanings of nudity, specifically pornography, documents e.g. Lenka Klodová (the topic of her doctoral thesis is a pornographic magazine for women), who uses pieces of pornographic magazines in her artistic creation.

Pornography, depicting hyper reality of anatomic details (Baudrillard 1996), approaches the human body in the mode of objectivization, depersonalization and instrumentalization. Contemporary society is characterised not only by sexualization (distinguishable e.g. in the commercial even without explicitly displaying genitals) but also by a certain pornoization, when culture changes into porn culture. This is evident for example in the connection of pop culture and porn in expression, gestures and poses in music videos of female singers (Levande 2008) or in linking the pornographic images with dance in the form of nude dancing, the purpose of which lies in showing intimate body parts to the audience from the closest distance possible (Schiff 1999). However, the connection of nudity and cultivated movement is not only characterized by pornographic eroticism (McKay \& Johnson 2008) but also by other possibilities of emphasis. The aim of this paper is to point out some of them.

To structure the paper further, I have chosen individual aspects of movement culture for its description, i.e. sport, movement education, movement recreation, movement therapy and movement art. Although this concept of the cultural subsystem is not generally accepted, a number of arguments have been given (Jirásek 2005, p. 112-153) and for this reason I am going to use this concept here too. This way we can perceive the movement culture as a place for realization of possibilities of authentic existence through movement and its cultivation, as a field for uncovering the purpose of human being with the assistance of movement.

\section{Sport}

Sport is characterised by an effort to maximum performance and victory in the conditions of a competition. However, in the European Union (and also at many departments dealing with kinantrophopogy in the Czech Republic), this word is used as a concept with a much broader meaning which is, in fact, comparable with the movement (physical) culture. Because of a terminological clarity, I emphasize that, not only in this paper, I conceive sport in its narrower specification. And if it is to be defined in its essence, maximizing the performance, then an attempt at victory and conditions of a competition must be present.

In connection with sport and nudity, probably the first thing that comes into one's mind is the culture of Ancient Greece and its tradition of participating in a competition completely naked (Olivová 1979, Hejduk 2007). However, we should not simplify phenomena that are, in themselves, much more complex. That is to say, back then it was not about sport events but religious ceremonies. That is why we can speak of Olympic Games or other Pan-Hellenic competitions, which we see as sporting events 
today, only from this point of view. In other words: The fact of nudity with the participating competitors is without doubt; nevertheless, the meaning of this was not athletic but religious.

Not only every culture and society but also every generation ascribes its own determining values connected to the naked body. It is not necessary to perceive nudity only in the frame of sexuality. It is not nudity that is a question of morality but the imagination related to sexual levels of nudity. While we are able to accept the heritage of Ancient Greece concerning the naked figures of athletes, it is probably unthinkable at similar events nowadays. Shyness and prudery regarding nudity but also its sexualization and erotizacion have a cultural and temporal context. If we disregard nudist beaches, saunas and similar rather closed communities, it seems that nudity as a natural phenomenon is rather dead in today's sporting environment: on the other hand, we can encounter "pornographic eroticism", "athletic eroticism" and other sexualized conception of bodies in movement, characterized by staring spectators (McKay \& Johnson 2008).

Contemporary use of nudity in the sporting context is determined neither by religious nor by sports motives. The instrumental conception of nudity is obvious in the growing intensity of athletes posing for erotic magazines, calendars and other press (Weaving 2005). Here, sport is merely an instrument for obtaining attractive bodies that are visually interesting for publishers; nevertheless, this is not related to genuine values of sport (performance, competition) in any way; possibly, some items from the sporting environment (balls, showers, body positions imitating sport activities etc.) are used as a background against which the bodies are displayed. So it is not about nudity in sport but about sexualization of displayed bodies using (or abusing?) the sporting environment.

The real connection of nudity and sport can be observed in three levels: the nudity (or partial nudity) of the actual sportsmen; the environment of sport using nudity of persons from the sportsman's team; the nudity of the spectators. Each of these levels can be briefly illustrated with an example.

The first case is the naked (or partially naked) body of a sportsman. While sometimes it is about functionality of sport clothing (be it for a potential increase in the performance or aesthetic criteria for judging), it is possible to view the gear that emphasizes features in a similar way as was the case with drapery in ancient sculpture. So it is not directly about nudity but about accenting body parts with gear that fits tight; within various sports. Such nudity or its proximity is surely something befitting the category of the natural and does not have to be made different with the dimension of sexualization. A different scenario is, however, the emphasis of nudity of sport gear with the goal of accenting not naturalness but sexual connotations of the physical; thus, the effort is not to cover certain body parts but to reveal them, to make them visible.

Nevertheless, it is possible to add the sexual context to the body of a sportsperson without them even knowing. Cases where breasts are visible under a sweaty t-shirt or raised skirts reveal other body parts of sportswomen are growing in numbers. And these parts are drawn closer by photographers seeking juicy details that can be put on web sites or published in other media. Precisely this "staring" at accidentally revealed body parts is a sign of accentuated erotization, sexualization or even pornoization of culture. This fact does not so much concern sportspeople themselves (they, in many cases, may not realize this accidentally emphasized nudity), as it does the spectators, when the phenomenon of spectatorship changes into voyeurism. "Hunt for sensations in sport reporting makes us look at sport in the manner in which we would not have looked at it or would not have wanted to by ourselves. Camera lenses bring closer uncontrolled mimics of the faces of runners, deadly crashes of skiers and car drivers, we repeatedly gape at accidentally uncovered intimate body parts of sportspeople." (Pelcová 1999, 156). 
The second element of sports events within the personal level lies in teams that, besides sportsmen, support the sport performance. With some types of sport (e.g. Formula 1 races), the background is formed by attractive women, who are dressed only partially or not at all. Also here nudity is not anything natural, but it participates in the sexualization of sports events.

The third dimension is contemporary accentuating body nudity in the role of fans and spectators. Be it something rather accidental like exposure of intimate body parts in the moments of strong emotions (cheerfulness over a goal) or completely purposeful celebration after the sport event combining alcohol and dance in connection with e.g. elevation of a dancing girl on a stand and her exposure. This is always about nudity that diverts from its naturalness toward attracting attention; nudity that is drawn closer.

The theme of nudity and sport can also be seen, nevertheless, somewhere on the border or interface of both phenomena. For example body painting, during which process sports (football) jerseys are painted on naked bodies; this leaves the body in its natural nudity but also covers it visually with a layer of paint. A more complicated connection is with new sport branches which are purposefully placed on the edge of sport and visualized sexuality. One of them could be, for instance, "aerobic striptease" combining dance and sexual movement of professional strippers. This new "sport" is connected with the name of Carmen Electra (see http://www.aerobicstreptease.com/), offering sets of DVDs with instructions for imitation of this sexuality. Or, "nude dancing" which is not a dance with any choreography or aesthetic dimension of movement but a pure intention to arouse perverse interests, sexual lust and fantasy (Schiff 1999, 10). Could "gaping at details of women's genitals" (ibid.) be called a dance at all?

Post-modern culture, however, does not stop at the natural border of the human body and it corrupts common understanding of it by extending the view that goes inside the body. Some aspects of this effort surely are worthy of gratitude (medicine including prenatal medicine), yet others are without doubt controversial. (Is it possible to call it nudity if we speak about e.g. pornographic details of genitals displayed out of any context of the human body? The manner of pornographic visualization and its consumption deserves much deeper reflection, but, in the given context, this topic must remain disregarded.) Where is the ethical limit of a respectful approach towards the living human body but also after the death of an individual? Besides scientific and pornographic discourse, we can also consider the artistic interpretation, including corruption of the natural point of view of the body. A paradigmatic example could be the very controversially judged exhibition "BODIES...the Exhibition", displaying preserved human bodies with various layers of tissue peeled off that are supplemented with sports gear (above all else, balls from various sports) so that it imitates sporting movement.

Thus, the sense of visualization in the field of sport is never unambiguous and unique. It goes from naturalness and functionality up to direct erotization, sexualization and pornoization. But the effort of kinantropology should be to support the original standpoint and, if possible, to prevent sport from changing into a tool of other phenomena not authentically connected with it. This is not a question of puritan prudery or turning away from social changes bringing openness and relaxation that would have been unacceptable in the past; it is about strict discrimination of meanings that could be interconnected, from those that are dissimilar.

\section{Movement education}

In this area of the cultural subsystem of movement culture, it is primarily the educational and instructional potential of human movement, in various dimensions, that is accented: movement as a means of education (education through movement), as its part (education of movement) or its content 
(education about movement). Just to reiterate again, let it be said that avoiding using the standard term 'Physical Education' is not motivated by an effort to be original at all costs but a form of possible defence against a potential dualistic connotation, a preference of holistic personality to excluding the physical out of the entirety of the human way of living, it is stressing education not toward the body but toward a long-term applied movement.

Also with movement education, we can look back to ancient Greece where nudity along with athletic development and pederastic relationships become a norm of education in palestras and gymnasiums (Hejduk 2007).

The culture of naked movement within the field of movement education came into life in 1920s Germany, where the teacher Adolf Koch founded a chain of private schools offering not only gymnastic exercises and naked exercising but also education, sexual education and outdoor activies (Jefferies 2006). Despite the fact that these schools were closed in 1932, they still demonstrate the endeavor for revitalization of the Ancient-Greek ideal of a natural naked body in movement, as indicated by the Ancient Greek title for school: gymnasion (gymnos=naked). When it comes to educational transformation, the fact that today's grammar schools do not practise movement nature in physical nudity is surely not the most crucial loss.

\section{Movement recreation}

This sphere of movement culture is defined by movement realized in one's free time, sharing the following characteristics: recreation, regeneration and relaxation.

Nudity and recreation are interconnected especially in the movement of nudists and naturists who perceive shedding one's clothes as something natural; they even consider it a support of social equality, an emphasis on the essence of humans and their equal status, getting rid not only of clothing but also social, economic and political differences. "Culture of a free body" is not only limited to nudist beaches but is also practised in camps where nudity is not supposed to be a source of distraction or excitement. On the contrary, it is supposed to signify a natural demonstration of the human way of being.

At first sight, it is obvious that there are cultural and social differences in understanding nudity and in the meaning ascribed to it. As an example, we can have a look at the beginning of the $20^{\text {th }}$ century in England or Germany. While the former nation was shocked by unisex saunas, nude bathing and the exercising of both sexes in one place at the same time, for the latter it was a common cultural habit. Nudism was introduced to Great Britain and the United States of America from the experience of Germans. It was in Germany that it gained widespread popularity. Naturism and Nudism are connected with a certain degree of ascetism but also with physical movement and with the recreation sphere of movement culture. And this connection exists to this day - e.g. German nudists are organized in an association that is a part of the German Sports Federation (Krüger, 1991). It is probably in German society and culture that the ancient ideal of the beauty of the naked body in movement is most alive, lacking the postmodern erotization.

As opposed to today's tension and disagreement between the tolerance of the pornographic industry and business and, at the same time, the prudery of not allowing any public display of a naked body [see e.g. the television sensation caused by the probably unintentional exposure of Janet Jackson's nipple (Levande 2008)], German society understands the naked body as a form of human naturalness. Naturalness of nudity means de-erotization of the body so that it has no sexual aspects or connotations. In the 1920s and early 1930s, there existed many clubs and colonies, many rival 
associations of naturists (bourgeois and working class) with tens of thousands of members. They issued a magazine and very actively propagated a lifestyle freed from clothing (Jeffers, 2006). Among them was e.g. the Gymnosofic Society (from Hellenic gymnos = naked, sofia = wisdom). However, this existed only for a brief period of time. The term Freikörperkultur (culture of free body) connects this way of life not only with nudity but also with movement, with movement culture. Thus, not only the naked body but also the moving body is a characteristic feature of such an approach. German Nudism and Naturism are connected with the values of beauty, youth (and its rebellion against parents and their moral system), natural health (water procedures and sunbathing in fresh air and being naked at the same time), movement culture (keeping one's body fit through exercise, gymnastics and dance with possibilities of a free expression of the body), but also with race hygiene (Krüger 1991).

Today's Naturism and Nudism can be either a result of free will of individuals or small groups, or of an organized community that intentionally profits from and propagates its lifestyle through both national and international associations and organizations.

\section{Movement therapy}

Sense, goal and purpose of movement in movement therapy are given by its regenerative, possibly rehabilitative, character aiming at health of the personality.

Using a sauna is perhaps the most noticeable feature of nudity in regenerative therapy (at this time, precision of the classification is not important: without doubt, visiting a sauna could also be integrated into the sphere of recreation), although therapeutic procedures are applied on the naked body much more frequently (not only procedures using water). However, there is one fundamental difference that is obvious in comparison with other forms of movement, thus, other spheres of movement culture: it is the certain intimacy and privacy. Nudity does not gain any characteristics of erotization or other symbolic meanings we could see in the sphere of sport. Nudity stays nudity, naturalness; it does not gain any social connotations. That is why there is nothing else to add to it because, in a given context, it is defined by the frame of meaningfulness and functionality.

\section{Movement art}

The last sphere of movement culture is characterised by aesthetic aspects of movement, demonstration of values of beauty. This category is probably the least obvious because we can incorporate into it both the sphere of sport (ballet, dance, modern gymnastic, figure skating, diving and many other sports) and other spheres, be they of movement culture or artistic ways of expression. Elegancy and grace, harmony, rhythm, purity of movements, individual creativity and interpretation are the values accented by movement art.

Interconnection of eroticism and sex with artistic movement could be indicated by the language itself - for example, in India until the 1920s dance was synonymous with the word prostitution (Bishop 1997). With this, at the same time, we are getting onto very unstable ground if we speak about concepts. It is probable that movement art becomes the least united subsystem because its necessary connections must be perceived both in the sphere of movement and in artistic transformation of reality. The theme of nudity connects us simultaneously with processes of education and possibilities of visualization of the naked body in arts (Poling \& Guyas 2008).

With artistic depiction of human physicality, very often, nudity is an opportunity to point out beauty. The history of art presents a large potential for how to register a body in movement or to 
transform something from its realistic being into a shape that enables certain ideological and semantic transcendence. What can be a part of this transfer is a certain element of erotization when beauty assumes features of certain attractiveness and sparkling passion. Nevertheless, if a certain degree of such transformation escalated into the mode of sexualization and pornoization where the beauty itself would become insufficient for sexual arousing, it would cross the sphere of art to a different semantic world. Beauty that can also acquire erotic connotations is an essential component of the artistic standpoint toward the world and life, it is an expression of personal unity, while pornography is, above all, a sexual commodity of the market that does not have to contain aesthetic qualities but can be reduced to an explicit sexual teasing and its marketability. What we can also do is significantly make subjective certain limits or criteria for differentiation of this phenomena because "if someone believes that sexuality represented in a work of art (or embodied in a sporting performance) is morally or aesthetically questionable, then this work (performance) is - for this particular individual-rather pornographic than erotic" (Guttmann 1996, p. 179).

Movement art, more than any other sphere of movement culture, when being judged, depends primarily on the performers and the spectators, exclusively on their perception, taste and discernment. What is beautiful for someone is less beautiful for someone else, but aesthetic characteristics of a certain phenomenon or performance should be the central prism through which we differentiate this individual sphere of movement culture.

\section{Conclusion}

Nudity in the environment of movement culture, therefore, does not seem to be a straightforward and distinct phenomenon (Descartes' epistemological requirement) but, on the contrary, something rather complex and multi-layered. That is why, in the issue of interconnection of nudity and the moving body, one's personal attitude cannot be so recklessly decided by a simple "for" or "against". It depends on the context, meaning and sense; that is the determining factor in a given situation.

It seems, though, that, for the sphere of kinanthropology, we could attempt to come up with one generalization: as opposed to media, especially popular informants, representatives of the kinanthropological field (to be precise, not only scholars-scientists but also teachers, students and other representatives of the scholarly public) should (possibly openly) incline toward naturalness and functionality of nudity within the frame of movement. The functional connection of the naked body and naturalness, in some cases surely with the atmosphere of erotic sparkling, is a dimension worth supporting because it can be an authentic component of movement culture. However, when it comes (particularly) to the sporting environment and its prospective values of sexualization and instrumentalized pornoization, exceeding the limits of movement culture through an interest not in the beauty of human body in movement but in sexual teasing and possibly financial profit, we should stand against this situation with valid critical arguments. The purpose of this paper is precisely that.

\section{REFERENCES}

Baudrillard, J. (1996). O svádění. Olomouc: Votobia.

Bishop, C. (1997). Lidský duch a sexualita. Praha: Knižní klub a Práh.

Guttmann, A. (1996). The Erotic in Sports. New York: Columbia University Press. 
Hejduk, T. (2007). Od eróta k filosofii: studie o Erótu se zrètelem k Sókratově filosofii. Červený Kostelec: Pavel Mervart.

Heller, J. (1988). Starověká náboženství. Praha: Kalich.

Jefferies, M. (2006). "For a genuine and noble nakedness"? German naturism in the Third Reich. German History, 24(1), 62-84.

Jirásek, I. (2005). Filosofická kinantropologie: setkání filosofie, těla a pohybu. Olomouc: Univerzita Palackého.

Krüger, A. (1991). There goes this art of manliness: naturism and racial hygiene in Germany. Journal of Sport History, 18(1), 135-158.

Levande, M. (2008). Women, pop music, and pornography. Meridians: feminism, race, transnationalism, 8(1), 293-321.

Levine, P. (2008). States of undress: nakedness and the colonial imagination. Victorian studies, 50(2), 189-219.

McKay, J. \& Johnson, H. (2008). Pornographic eroticism and sexual grotesquerie in representations of African American Sportswomen. Social Identities, 14(4), 491-504.

Mowry, M. (1999). Dressing up and dressing down: prostitution, pornography, and the seventeenth-century English textile industry. Journal of Women's History, 11(3), 78-103.

Olivová, V. (1979). Lidé a hry: historická geneze sportu. Praha: Olympia.

Payne, R. M. (2000/2001). Beyond the pale: nudism, race, and resistance in The Unashamed. Film Quarterly, 54(2), 27-40.

Pelcová, N. (1999). Elita a marginalita: o sportovcích a divácích v době postmoderní čili sportovní apokalyptika. In Hogenová, E. (Ed.), Filosofie sportu (pp. 155-158). Praha: Univerzita Karlova.

Poling, L. H., \& Guyas, A. S. (2008). Removing the fig leaf: issues and strategies for handling nudity in the art room. Art Education, 61(1), 39-43.

Schiff, F. (1999). Nude dancing: scenes of sexual celebration in a contested culture. Journal of American Culture, 22(4), 9-16.

Tortorici, Z. (2007). Masturbation, salvation, and desire: connecting sexuality and religiosity in colonial Mexico. Journal of the History of Sexuality, 16(3), 355-372.

Weaving, Ch. (2005). She Strips... She scores! An Analysis of Women Athletes Posing Nude. 33rd Annual Meeting of the International Association for the Philosophy of Sport, Olomouc, 15-18.09.2005. 